\title{
VERSITA
}

\section{Csaba Weiner}

\section{Ludvig, Zsuzsa (ed.) Eurasian Challenges: Partnerships with Russia and Other Issues of the Post-Soviet Area. East European Studies, No. 4, Budapest: Institute of World Economics, Centre for Economic and Regional Studies, Hungarian Academy of Sciences, 2013, 163pp.}

Following nine volumes in Hungarian, this one is the fourth published in English in the East European Studies series. The book focuses on the developments in East-European and post-Soviet countries. While in this case most of the authors are external, all of them are part of the network that has been bringing together young specialists and senior experts from both Hungary and abroad for a long time, but particularly since the so-called CIS Project, launched in 2007 within the Institute of World Economics of the Centre for Economic and Regional Studies of the Hungarian Academy of Sciences (IWE-CERSHAS). The second and third volumes of The East European Studies have been already reviewed and kindly published in the Baltic Journal of European Studies (vol. 1, no. 2, September 2011, pp. 211-213 and pp. 214-216, respectively). Since that time, the former funding has been replaced by a Hungarian Scientific Research Fund grant for a three-year research entitled 'Russia as Political and Economic Centre in the Eurasian Space at the Beginning of the $21^{\text {st }}$ Century: Sphere of Influence, Competitors and Consequences for Europe and Hungary'. All the articles can be downloaded from the same website (at http://www.cisproject.hu).

The project leader and editor, Zsuzsa Ludvig of IWE-CERSHAS, collected six interesting articles, of which four deal with the relations of a particular country or region with Russia (Chapter 1: 'Russia as a Partner'), while one of the remaining two papers offer a new concept of public-private partnership (PPP) in Ukraine as a socio-economic institution. The second study addresses the economic and social crisis in the Northern Aral Sea Region, stemming from the environmental catastrophe, accordingly (Chapter 2: 'Selected Issues of the Post-Soviet Area'). All the articles were finalised at the end of 2012.

The first article, by Volodymyr Sidenko, offers insight into the problem of Ukraine's multivector integration policy, which for the most part of the 1990s was concealed because Ukraine preferred the relations with Russia and other countries in the Commonwealth of Independent States (CIS). As the author summarises it, the reintegration results were frustrating but relations with the 
European Community were at its initial stage. Before 1998, Ukraine pursued a rather restrained regional integration policy and a more active global policy (with the World Trade Organisation, or WTO, and the global financial institutions). At the end of the 1990s, the change in Ukraine's integration policy was fuelled by the fears of economic domination by Russia and losing national sovereignty as well as by Ukraine's new objectives of qualitative change in its development. But, Sidenko continues, the turn towards the West and the adaptation of the model of European integration, coupled with the strategic partnership with Russia and the free trade in the CIS, were disrupted by the project of the Common Economic Zone, or CEZ (also Common Economic Space or Single Economic Space) in 2003/2004. The conflict between the two integrations was resolved by political instruments, as the new President Viktor Yushchenko (2005-2010) politically suspended (!) the CEZ project. Sidenko disagrees with the popular evaluation of the period of the triumph of the Orange Revolution (from January 2005 until August 2006) in terms of opportunities and results of the EU integration process. Concerning the EU Eastern Partnership, the author declares that this was treated as a supplementary instrument that enables the acceleration of Ukraine's integration into the EU. Ukraine did not want to wait for long-term prospects and the Yushchenko era revealed Ukraine's dualism with regard to the European integration. Sidenko lists three major reasons that have brought Ukraine's integration policy to a stalemate, from a multivector or alternate vector integration policy to a vectorless policy.

First, the internal development of Ukraine under the new President Viktor Yanukovych has been diverting from the EU standards in a number of areas. Second, the European Union, facing the crisis in the eurozone, has come to a dilemma whether to continue the enlargement. Third, the efforts of Russia to pull Ukraine into the Eurasian integration communities have seriously intensified. As to the economic dilemmas for Ukraine, since 2010, the economic aspects have seemed to dominate the integration policy. Sidenko details the consequences of the future Deep and Comprehensive Free Trade Agreement (DCFTA) on Ukraine's agrarian and foodstuff export and industrial products, including industrial goods with higher value-added and technology-intensive goods. $\mathrm{He}$ also emphasises the potential negative response on the part of the Customs Union of Russia, Belarus and Kazakhstan. Among these circumstances, the Eurasian alternative seems to offer a number of ready solutions. These include more than Russia's offer to decrease gas prices and the cancellation of export duties for Russian oil and oil products.

Sidenko highlights that the Eurasian alternative also poses severe challenges to the Ukrainian economy, including the inflow of Russian capital to seize control 
in strategic areas. Still, the overall balance seems to be more in favour of the EU integration, but medium-term expenses need to be identified as well. The author shows in detail how the Ukrainian government seeks the expansion of the field of available opportunities in this situation: (i) by free trade agreements, (ii) by involving China in its strategic relations, and (iii) by its own vision of cooperation with Eurasian economic structures.

Finally, Sidenko turns to the concept of the Pan-European Economic Space (PEES) as a possible solution for Ukraine and lists the basic components of the PEES and then admits that this outline has now a rather speculative character. Three models through which the PEES may progress can be drawn: (i) the principle of concentric circles, (ii) the bipolar Europe model, and (iii) the model of the multiregional big Europe. After introducing these models, the author claims that the most realistic way is to use an eclectic approach based on the above mentioned three models. In the final paragraphs, the paper mentions a wider perspective for the proposed PEEC, which may evolve into a broad EuroAsian economic space from the Atlantic to the Pacific. The reviewer can only add that first we will see whether the Association Agreement and the DCFTA between the EU and Ukraine will be signed at the Eastern Partnership Summit in Vilnius due in November 2013.

In the second article, Annamária Kiss investigates, in a very sophisticated manner, one of the world's most vulnerable and unstable regions, the South Caucasus, which is located at the crossroads of three regional powers (Russia, Turkey, and Iran). The article focuses on Russia-South Caucasus relations, presenting the main contradictions in the fields of security and economy and emphasising the complexity and uncertainty of bilateral ties. Kiss also addresses the topic of how Russia's influence has been changing in the region, arguing that there are many examples of Russia giving up its position, and that developments in the North Caucasus are strongly interlinked with those of the South Caucasus as well. To highlight the political and security challenges in this crisis-ridden region, (i) the Russia-Georgia War of 2008, (ii) the Nagorno-Karabakh conflict, and (iii) the Safarov case are analysed separately. The Russia-Georgia War of 2008, which, as the author claims, was an unavoidable consequence of the tense Russia-Georgia relations and became truly global, had long-term effects, including the housing of new internally displaced persons (IDPs) and the removal of Georgia's NATO membership from the agenda. At the same time, seeking membership in regional and international organisations is a primary goal of the South Caucasian states. Without a common strategy or united position, Western influence was limited in conflict resolution. On the contrary, Russia was back as an ultimate guarantor of peace, demonstrating that it would not lag behind the 
events. Concerning the Nagorno-Karabakh conflict, the author underlines that the Organisation for Security and Co-operation in Europe (OSCE) seems to fail on presenting visible results. The Safarov case concerns Hungary and is written by a Hungarian author with an utmost objective approach to a set of arguments. Kiss draws attention to the changes in military spending in the region due to the intensification of the conflicts. A subchapter is also devoted to the issues of Islamist mobilisation in the North Caucasus, terrorism, as well as to the mistrust and xenophobic attitudes towards Caucasian people. Kiss believes that the 2014 Winter Olympic Games will be a litmus test for the counter-terrorist authorities and the Kremlin itself.

As to the economic challenges, in the second part of the article, Kiss emphasises that the three South-Caucasian states have different economic potential. Contrary to Armenia, Georgia is endowed with big agricultural potential and Azerbaijan contains large hydrocarbon reserves. Kiss outlines the general economic situation in, and the effects of the recent economic crisis on each South-Caucasian state, and attempts to measure Russia's influence in the region by using the following four evaluation criteria: (i) trade relations, (ii) foreign direct investments (FDI) and loans, (iii) remittances, and (iv) influence in the energy industry. The author concludes that Russia has a great weight in almost every field of Armenian economy and, as a result, will determine the economic path of Armenia in the foreseeable future. Russian influence in Georgia has diminished considerably but increased to a high extent in Abkhazia and South Ossetia. However, Russia still has important investments in Georgia's energy sphere. The start of Russia's trade war with Georgia is well outlined in the article, but what is lacking is a discussion of its importance and ending in the light of Russia's accession to the WTO. Finally, Kiss believes that Russia has little direct control in Azerbaijan, but Russia is the main source of imports, and remittances are notable as well.

In the third article, Marco Siddi takes a look at Italy-Russia relations, pointing out that Rome has maintained a positive dialogue with Moscow since the Second World War, and Italy does not challenge Russia's narrative of the "Great Patriotic War" either. Although political differences have not been an obstacle for the establishment of friendly relations, a further improvement took place during Vladimir Putin's era and throughout Silvio Berlusconi's career in power. In fact, Berlusconi was one of the most enthusiastic supporters of co-operation with Russia within the EU and NATO. For Italy, Russia is not just a key factor in European security matters, but the pivot of the Italian economic strategy in the post-Soviet space. Siddi details how trade relations had been developing since the 2000's, and particularly, most recently, although more explanation would enrich their value. Nevertheless, the author concludes that Italian exports 
to Russia have constantly been much lower than those from Russia to Italy, due to the energy imports from Russia, which represent the bulk of Russia's exports to Italy. Moreover, recent trend shows that the weight of fossil fuels is further increasing. On the other hand, naturally, Italian exports to Russia are more diverse. Siddi characterises this situation as complementarity of the two countries' productive systems: Italy's dependence on imports of fossil fuels and Russia's need for Western technology. It is shown that both Italian FDI in Russia and Russian FDI in Italy increased exponentially during the 2000s. But according to the author's calculations, based on yearly FDI data for the period between 1992 and 2010, Italian FDI in Russia is twice as much as Russian FDI in Italy. However, Siddi agrees that the Italian FDI in Russia is still limited and lists factors that could help increase Italy's chance of taking advantage of potential opportunities. Owing to the importance of those, the author separately explores the Russian-Italian energy partnership. Energy co-operation continues to play a leading role, and the article offers detailed examples from the companies ENEL and ENI. Naturally, the South Stream pipeline project is the centrepiece of the analysis. The article addresses many of the issues surrounding the problem, which, however, can raise further debates among experts as well. Finally, Siddi turns his attention to other sectors where Italians and Russians co-operate in. As to the Russian companies operating in Italy, a few companies are named, but, unfortunately, without details about their assets and specific local activities.

In the fourth article, Zsuzsa Ludvig discusses in detail the impacts of the three major economic crises (the transition crisis, the 1998 Russian financial crisis, and the recent economic crisis) that Russia has faced since the 1990s on the export performance of six Central and East European (CEE) countries (including Poland, the Czech Republic, Slovakia, Hungary, Romania and Bulgaria) on the Russian market. Examining the trade impacts of the transition crisis, the paper warns that already before the dissolution of the Soviet Union and the start of Russia's transition, significant changes occurred in the geographic structure of Russia's foreign trade. In addition, trade patterns were changing in the CEE countries as well. Ludvig shows how the commodity structure of the CEE exports changed during the 1990s and how unfavourable was the modification in Russia's export structure. Also, it is argued that growing trade deficit became the most important and problematic feature of the CEEC-Russia trade. As seen, the issue of this so-called 'energy bill' is touched upon in the third article by Marco Siddi as well. Zsuzsa Ludvig emphasises Poland's achievements on the Russian market, concluding that this business success disproves the basic premise that the CEE countries' decline in trade with Russia is closely connected with loosening political ties. Overviewing the consequences of the 1998 Russian financial 
crisis, the author states that exports from the six CEE countries decreased the most in 1998 and 1999 among the examined trade partners of Russia, due to lack of funds to finance their activities, and, in some cases, due to lack of state support and state guarantees. Consequently, total CEE exports reached their 1997 level only by 2003-2004. However, differences were significant among the CEE countries. Ludvig believes that export achievements in the 2000s were attributable not to the improving political relations but to the Russian economic boom and the accession of the CEE countries to the EU. Moreover, transnational companies with subsidiaries in CEE countries changed their attitude (statistical recording or intra-firm agreement issue). Ludvig again comes to the conclusion that balanced and friendlier political relations had some positive effect on the economic relations, but the export growth was due to other factors. As to the third crisis period, a new feature can be observed: the extent of the decline in the CEE exports to Russia was more or less the same as the average shrinkage of Russian imports. The impacts seem to be not as long-lasting in the CEE region as the previous ones. The author thinks that these are mostly associated with the dominance of transnational companies in CEE exports to Russia.

The fifth article, the shortest in the volume, by Ievgen Cherevykov, describes briefly and in a straightforward manner the Ukrainian PPP situation, focusing on the institutional background. According to the author, PPP is not only a contractual, but an institutional relationship between public and private entities. Using relevant literature, Cherevykov claims PPP is a powerful tool of public regulation in the context of investment, innovation, fiscal, competitive, social and regulatory policy. To offer a new concept, the behavioural, the cognitive, the associative, the regulatory and the constitutive nature of PPP is highlighted. The author lists the advantages of PPP, arguing that the potential of using PPP in Ukraine is high, but underestimated (or, as the author of this review believes, underutilised). The analysis substantiates these statements and specifies the reasons. A table compiled by Cherevykov provides insight into the characteristics of the most significant "quasi-PPP" investment projects in Ukraine. However, perhaps, it would have been interesting to read more about these projects, as case studies, particularly in light of the negative experiences with PPP implementation in other countries. Cherevykov lists the most relevant legislations that govern the economic relations between public and private sectors and shows the special legislations regulating the state's interaction with the private sector within the framework of PPP. The PPP Law specifies the following PPP forms: concession, joint activity, and others. The author recommends developing PPP in Ukraine on the basis of the PPP Law, which should serve as a framework law. For that, six requirements should be met. Finally, Cherevykov turns his attention to the 
problems of PPP at local level, arguing that despite the potential, the activity of local authorities to involve the private sector remains extremely low, due to the institutional reasons, which are also identified in the article. On the other hand, Cherevykov admits that the private sector's willingness to participate in infrastructure projects remains quite low as well. As a solution, the author also shares his suggestions for changing the situation.

The sixth and final article, by Alpár Szöke, examines the effects of inappropriate irrigation in the Soviet Union from the rivers feeding the Aral Sea on the environment and, in turn, on the economy and society, and, on the other hand, points out the achievements made in the post-Soviet period to repair the damages. Szöke's hypothesis is that the performance of a region's economy is dependent on the quality of the environment surrounding it. The article declares that the Aral Sea Basin was a prosperous region until the 1960s and the economy was based on fishing industry. Until that, the irrigation did not have a major effect on the sea but the expansion of agricultural projects led to gradual shrinking of surface water levels, higher salinity, and growing pollution. Not only did the large quantities of fertilisers damage the soil quality, but they were carried into the sea as well. The article shows how, regardless of that, cotton production increased in the Soviet republics. Due to the high salinity level in the Aral, all the fish died out leaving a large per cent of the local population unemployed and the economy in ruins. The dust and salt from the bottom of the dried-up seabed (the desertification process) are being blown onto adjacent agricultural fields, making cultivation impossible. The climate of the region has become more extreme. But not only were the agricultural activities hindered, serious health consequences have been registered in the area as well. Health deterioration has had a negative effect on the economy as well. The article focuses on the Northern Aral Sea ('Little Aral') - a region which, at present, belongs to Kazakhstan. (The waters were split in two in 1990.) It is noted that the above-mentioned problems also caused a large wave of emigration from that region. Before analysing the Northern Aral Sea Region, Szöke studies the environmental theories and claims that in the Soviet era "[t]he general belief was that even though the sea level would be substantially reduced this is a 'worthy' trade-off as one cubic meter of water brings more value when used for irrigation than it would bring in the Aral Sea" (p. 139). Unfortunately, only a few scientists warned against the serious effects. In the post-Soviet times, the environmentally and socially conscious policies introduced by the government reversed the negative trends, proving that both the biodiversity and the economy could be restored. The biggest achievement was building a dam, which was finished in 2005, on the southern border of 'Little Aral' in order to prevent water 
from flowing away. The dam helped stabilise the water level, the sea territory and the sea volume, which, in turn, made it possible to restart industrial fishing activity in the region. This achievement fuels hopes for further improvements in the future. Szöke devotes a subchapter to both the reorganised fishing industry and the role of the state in environmental improvement, economic growth and rising social standards. The particular value of this article lies in the fact that the author not only gathered relevant literature and used a quantitative formula to evaluate the situation from a point of view of sustainability (and put theories into practice), but made a field trip to the Northern Aral Sea to obtain first-hand information. However, maybe due to this involvement, some statements of the article seem slightly repetitive. It would be interesting to read a similarly highquality in-depth study on the developments of the 'Big Aral' (the Southern Aral Sea) as well.

As shown above, this volume is an excellent compilation of the research results gained during this phase of ongoing work. Moreover, the volume is, again, nicely edited with tables and figures included to validate the authors' arguments. The abundance of references to the articles in the volume can help the interested reader dig deeper in the respective topics. The editor in her foreword expresses the authors' hope that they could provide interesting and valuable studies and could contribute to the understanding of these challenging issues. After having read it, the reviewer is really convinced that these goals have been achieved and the volume proves useful in the hands of academic people, university students, and people working in government administrations as well.

Csaba Weiner, Ph.D., is Senior Research Fellow at the Institute of World Economics of the Centre for Economic and Regional Studies of the Hungarian Academy of Sciences, Budapest, Hungary. After completing his civil service at the Department of Social Sciences of the István Széchenyi University in Györ, Hungary, with his bachelor's degree in 2000 and the master's degree in 2003, he joined the Institute of World Economics as Assistant Research Fellow in 2003. His main areas of research interest are the Russian economy, the energy sector of the former Soviet Union countries, foreign direct investment in and from Russia and Russo-Hungarian relations. He has authored more than 30 publications on these and other related topics. Weiner earned his Ph.D. in Regional Science from the Széchenyi István University in 2011 after defending his doctoral dissertation entitled "The Position of the Russian Gas Industry in the World Economy and its Influence on the International Cooperation". 